\title{
Action plan for healthy agriculture, healthy nutrition, healthy people
}

\section{Piano d'azione per un'agricoltura e una nutrizione sane per la salute pubblica}

\author{
Artemis P. Simopoulos, ${ }^{1}$ Ole Faergeman, ${ }^{2}$ Peter G. Bourne, ${ }^{3}$ Raffaele De Caterina $a^{4,5}$ \\ ${ }^{1}$ The Center for Genetics, Nutrition and Health, Washington, DC, USA; ${ }^{2}$ Department of Internal Medicine and Cardiology, Aarhus \\ Sygehus University Hospital, Aarhus, Denmark; ${ }^{3}$ Green Templeton College, University of Oxford, UK; ${ }^{4}$ Università degli Studi \\ “G. D’Annunzio", Chieti, Italy; ${ }^{5}$ Fondazione Toscana Gabriele Monasterio, Pisa, Italy
}

\section{Presentation}

In October 2010, the World Council on Genetics, Nutrition and Fitness for Health promoted a scientific meeting in Ancient Olympia, Greece, on the theme Healthy Agriculture, Healthy Nutrition, Healthy People. The meeting focused on evolutionary aspects of human diet through the life cycle in terms of genetic predisposition, overall health, prevention of disease and of unhealthy behaviors, such as poor physical activity, and dietary changes caused by the introduction of modern agriculture, from the Agribusiness to systems of food production, from climate changes to the needs imposed by urban agriculture and architecture. Nutritional medical (mostly cardiological) and political aspects of disease prevention through healthy dietary habits and physical activity have always been seen in isolation. The meeting, the first of its kind, treated such aspects together, recognizing the importance of integrating and initiating a dialogue between these disciplines. The meeting gathered together experts in cardiovascular prevention, nutrition, as well as politicians, for a global discussion of these themes. A summary statement was then compiled, focusing on the main themes on which a consensus had been reached. I strongly believe that such themes have great relevance for public health, raising the need for disseminating them as widely as possible. I am thankful to the Editor of the Italian Journal of Medicine for allowing this summary document to be made available for the first time in Italy.

\section{Presentazione}

Raffaele De Caterina

Nell'ottobre 2010 il World Council on Genetics, Nutrition and Fitness for Health ha promosso un convegno scientifico nell'antica Olimpia, in Grecia sul tema Agricoltura e Nutrizione Sane per la Salute Pubblica (Healthy Agriculture, Healthy Nutrition, Healthy People). Il Convegno ha avuto per oggetto gli aspetti evoluzionistici della dieta attraverso il ciclo della vita in termini di predisposizione genetica, salute, prevenzione delle malattie e di stili di vita sedentari; le variazioni dietetiche portate dalla moderna agricoltura, dall'Agribusiness, dai sistemi di produzione del cibo, dai cambiamenti climatici e dalle necessità di agricoltura e architettura urbane. Gli aspetti nutrizionali, medici (e precipuamente cardiologici) e politici della prevenzione delle malattie attraverso una corretta alimentazione e l'esercizio fisico sono stati sempre visti in maniera isolata. Il Convegno, primo nel suo genere, ha trattato questi aspetti in maniera unitaria, riconoscendo l'importanza dell'integrazione e del colloquio tra queste discipline. Il Convegno ha radunato esperti di prevenzione cardiovascolare, nutrizione e rappresentanti della politica per una discussione globale su questi temi. Ne è seguito un documento di consenso riassuntivo dei punti principali toccati. E' nostra opinione che questi temi abbiano una tale rilevanza per la salute pubblica da rendere auspicabile una disseminazione la più ampia possibile. Ringraziamo pubblicamente l'Editore dell'Italian Journal of Medicine per rendere possibile tale disseminazione.

Raffaele De Caterina

\section{Introduction}

The Inaugural Conference on Healthy Agriculture, Healthy Nutrition, Healthy People of the World Council on Genetics, Nutrition and Fitness for Health was held at Ancient Olympia, Greece on October 5-8, 2010. The focus of the Conference was on the evolutionary aspects of diet throughout the life cycle in terms of genetic predisposition, health, disease prevention and sedentary lifestyles, the dietary changes brought about by modern agriculture, Agribusiness, food production systems, changes in climate and the need for urban agriculture and architecture, all of

\section{Introduzione}

Il Convegno inaugurale su Agricoltura e Nutrizione Sane per la Salute Pubblica (Healthy Agriculture, Healthy Nutrition, Healthy People) del World Council on Genetics, Nutrition and Fitness for Health si è tenuto nell'Antica Olimpia, in Grecia, dal 5 all's ottobre 2010. Il Convegno ha avuto per oggetto gli aspetti evoluzionistici della dieta attraverso il ciclo della vita in termini di predisposizione genetica, salute, prevenzione delle malattie e di stili di vita sedentari; le variazioni dietetiche portate dalla moderna agricoltura, dall'Agribusiness, dai sistemi di produ- 
which are influenced by governments, national and international policies. Therefore, the role of governments and international organizations was extensively discussed during the last session of the Conference by the participants from 20 countries representing six continents.

\section{General conclusions and recommendations}

Today we live in a nutritional environment that is very different from those to which we are genetically adapted. Major changes in our food supply accompanied the domestication of animals and the agricultural revolution about 10,000 years ago. Later, the industrial revolution and developments in food technology brought about further major changes in the composition of foods, one of the most important of which was a change in the quantity and quality of the various fatty acids. The content of saturated fat and omega- 6 essential fatty acids increased, whereas the content of

Correspondence: Artemis P. Simopoulos, The Center for Genetics, Nutrition and Health, 2001 S Street, NW, Suite 530, Washington, DC 20009, USA.

Tel. +202.462.5062 - Fax: +202.462.5241

E-mail: cgnh@bellatlantic.net

Italian translation and correspondence for the Italian part: Raffaele De Caterina, Ospedale SS. Annunziata, Via dei Vestini 31, 66013 Chieti, Italy.

Tel. +39.0871.41512 - Fax: +39.0871.402817.

E-mail: rdecater@unich.it

Key words: genetics, omega- 6 and omega- 3 fatty acids, prevention, chronic diseases, healthy agriculture.

The Action Plan was approved by the Members of the World Council on Genetics, Nutrition and Fitness for Health who also served as the scientific committee for the Conference: M. Aksoy, E. Bababunmi, P.G. Bourne, R.C. Casper, M.J. Castillo-Garzon, G. Chrousos, R. De Caterina, M. De Lorgeril, O. Faergeman, E. Ferris, S. Gopalan, J.X. Kang, A. Leaf, F. Leighton, D. Li, H. Okuyama, L. Pérusse, A.P. Simopoulos, C. Spirou, L. Tapsell.

Il Piano d'Azione è stato approvato dai Membri del World Council on Genetics, Nutrition and Fitness for Health che hanno anche servito come commissione scientifica per il convegno omonimo: M. Aksoy, E. Bababunmi, P.G. Bourne, R.C. Casper, M.J. Castillo-Garzon, G. Chrousos, R. De Caterina, M. De Lorgeril, O. Faergeman, E. Ferris, S. Gopalan, J.X. Kang, A. Leaf, F. Leighton, D. Li, H. Okuyama, L. Pérusse, A.P. Simopoulos, C. Spirou, L. Tapsell.

This work is licensed under a Creative Commons Attribution NonCommercial 3.0 License (CC BY-NC 3.0).

CCopyright A.P. Simopoulos et al., 2013

Licensee PAGEPress, Italy

Italian Journal of Medicine 2013; 7:128-134

doi:10.4081/itjm.2013.128 zione del cibo, dai cambiamenti climatici e dalle necessità di agricoltura e architettura urbane, le quali tutte sono influenzate dai governi e dalle politiche nazionali e internazionali. Per questo motivo il ruolo dei governi e delle organizzazioni internazionali è stato ampiamente discusso nell'ultima sessione del Convegno dai partecipanti provenienti da 20 paesi e rappresentanti 6 continenti.

\section{Conclusioni generali e raccomandazioni}

Al giorno d'oggi viviamo in un ambiente nutrizionale che è molto diverso dagli ambienti cui siamo geneticamente adattati. Cambiamenti maggiori nella disponibilità di cibo per la specie umana hanno accompagnato l'addomesticamento degli animali e la rivoluzione agricolturale circa 10,000 anni fa. Successivamente, la rivoluzione industriale e lo sviluppo delle tecnologie alimentari hanno portato ulteriori importanti cambiamenti nella composizione dei cibi, di cui uno dei più importanti è stata una variazione nella quantità e qualità dei vari acidi grassi. Il contenuto di acidi grassi saturi e di acidi grassi essenziali omega-6 è aumentato, mentre il contenuto degli acidi grassi omega-3 è diminuito. Uno sviluppo correlato direttamente all'industrializzazione è stato l'aumento intenzionale nel contenuto di acidi grassi trans prodotto dall'idrogenazione di acidi grassi poli- e monoinsaturi. Inoltre, una diminuzione del $30 \%$ nel contenuto di vitamine essenziali e minerali nella frutta e nei vegetali ha accompagnato l'uso di fertilizzanti chimici, prodotti con processi che necessitano di grandi quantità di energia e, probabilmente cosa ancor più grave, aventi come risultato la pericolosa distruzione del ciclo del fosforo. Nonostante queste e molte altre relazioni strette tra agricoltura e produzione di cibo da una parte, e problemi nutrizionali ed ecologici dall'altra, le politiche per l'agricoltura, per l'ambiente e per la nutrizione e la salute umane sono a tutt'oggi largamente scollegate. Nelle nostre analisi di priorità politiche appare ovvio che dobbiamo avere una visione più ampia di quella comunemente adottata, che almeno riconosca le complesse interrelazioni tra agricoltura, allevamento, salute umana, e i sistemi ecologici da cui dipende la vita sulla Terra.

Le presentazioni al Convegno hanno fatto notare che il genoma umano non è cambiato molto durante il periodo relativamente breve (10,000 anni) in cui sono avvenuti questi importanti cambiamenti nella dieta. E' pertanto probabile che malattie croniche, come alcune forme di malattie cardiovascolari, l'obesità, il diabete, il cancro, l'artrite, la malattia mentale e le malattie neurodegenerative, siano dovute, almeno in parte, a fattori ambientali comprendenti il cibo e ad altri elementi della vita moderna cui non siamo ben adattati geneticamente. Un'analisi degli studi epidemiologici 
omega-3 fatty acids decreased. A development related directly to industrialization was the intentional increase in the content of trans-fatty acids produced by the hydrogenation of polyunsaturated and monounsatured fatty acids. Furthermore, a 30\% decrease in the content of essential vitamins and minerals in fruits and vegetables has accompanied the use of chemical fertilizers, which are produced by processes requiring large amounts of energy and, perhaps most serious of all, resulting in dangerous disruption of the phosphorus cycle. In spite of these and many other close relationships between agriculture and food production on the one hand and nutritional and ecological problems on the other, policies for agriculture, for the environment and for human nutrition and health are largely disconnected. In our analyses, priorities and policies, we quite obviously need to take a broader view, one that at the very least recognizes the complex relationships between farming, human health, and the ecological systems on which life on Earth depends.

The presentations at the conference noted that the human genome has not changed very much during the relatively short period $(10,000$ years $)$ of these major changes in diet. It is likely, therefore, that chronic diseases such as certain forms of cardiovascular disease, obesity, diabetes, cancer, arthritis, mental illness and neurodegenerative diseases are due, at least in part, to an environment of food and other elements of modern life to which we are genetically not well adapted. An analysis of epidemiological studies of dietary fatty acids and coronary heart disease (CHD) indicated that, in contrast to almost all current recommendations, high amounts of dietary linoleic acid (the major omega- 6 fatty acid) from vegetable oils actually increase the risk of CHD. The production of vegetable oils such as corn oil and soybean oil are a major element of modern food production systems. It may, therefore, be very unfortunate that foods with a high ratio of linoleic acid (omega-6) to $\alpha$-linolenic acid (omega-3) of about 15:1, common in developed countries, are now spreading to developing countries adopting the agricultural and dietary practices of the so-called developed world. Studies of transgenic animals (the FAT-1 mouse) provided further support for the concept that the effects of high linoleic acid and arachidonic acid are detrimental and that the effects of $\alpha$-linolenic acid, eicosapentaenoic acid and docosahexaenoic acid are beneficial.

Decreasing omega- 6 fatty acids and increasing omega- 3 fatty acids in the diet, so that the ratio of omega- 6 to omega- 3 is reduced from typically $15: 1$ or more to ideally $2: 1$ or less is a nutritional policy that should be considered by national and international organizations, agricultural and health associations and the food industry. It is consistent with results of basic research, current epidemiology and studies of evolu- su acidi grassi alimentari e cardiopatia ischemica (coronary heart disease, $\mathrm{CHD}$ ) ha indicato che, in contrasto con quasi tutte le raccomandazioni attuali, alte quantità di acido linoleico alimentare (il principale acido grasso omega-6) da oli vegetali aumentano il rischio di CHD. La produzione di oli vegetali come l'olio di mais e di soia è un elemento caratterizzante dei sistemi moderni di produzione del cibo. Può essere pertanto un grave problema che cibi con un alto rapporto di acido linoleico (omega-6) su acido $\alpha$-linolenico (omega-3) di circa 15/1, comune nei paesi sviluppati, si stiano attualmente diffondendo nei Paesi in via di sviluppo che adottano le pratiche agricolturali e dietetiche del cosiddetto mondo sviluppato. Studi su animali transgenici (come i topi FAT-1) hanno fornito ulteriore supporto al concetto che gli effetti dell'acido linoleico ed arachidonico sono dannosi, e che gli effetti degli acidi $\alpha$-linolenico, eicosapentaenoico e docosaesaenoico sono benefici.

Una riduzione degli acidi grassi omega- 6 e un aumento degli acidi grassi omega- 3 nella dieta, in modo che il rapporto di omega- 6 su omega- 3 si riduca da un valore tipico di 15:1 o più a un valore idealmente di 2:1 o meno è una politica nutrizionale che dovrebbe essere considerata da organizzazioni nazionali e internazionali, associazioni agricolturali e di salute, e dall'industria alimentare. Essa è in linea con i risultati della ricerca di base, con le evidenze epidemiologiche attuali e con gli studi sull'evoluzione. Al contrario, l'introduzione degli acidi grassi trans non è stata supportata da alcun tipo di ricerca sui possibili effetti sulla salute pubblica, e la ricerca recente indica che gli acidi grassi trans conferiscono un rischio di CHD almeno altrettanto importante quanto quello dei grassi saturi. Analogamente, l'introduzione nell'alimentazione di grandi quantità di acidi grassi omega- 6 è stata supportata da ricerche che non avrebbero superato il vaglio degli standard attuali di qualità. Devono pertanto essere considerati attentamente gli effetti sulla salute di nuovi cibi e ogni variazione alimentare (quantitativa e qualitativa) proposta dagli agricoltori e dalle tecnologie alimentari, e dovrebbero essere effettuati studi pilota prima che questi cibi diventino disponibili per la popolazione generale.

La fenilchetonuria illustra come le interazioni tra l'introduzione alimentare di un nutriente e una forte ma rara - variante genetica determinino la differenza tra salute e malattia. Per converso, varianti genetiche molto più comuni, ma più deboli, interagendo con $\mathrm{i}$ nutrienti, possono influenzare moderatamente la salute in parti importanti della popolazione. Come esempio, il metabolismo dei nutrienti essenziali acido linoleico e $\alpha$-linolenico ad acidi grassi essenziali a catena più lunga è sotto il controllo di una serie di geni. Varianti comuni in tali geni influenzano l'efficienza di tali conversioni metaboliche, sì che le necessità alimentari per 
tion. In contrast, the introduction of trans-fatty acids was not supported by any kind of research into possible health effects, and recent research indicates that trans-fatty acids confer risk of CHD at least as great as that of saturated fat. Similarly, the introduction of high amounts of omega- 6 fatty acids into the diet was supported by research that would not have met current research standards. The health effects of novel foods and any dietary (quantitative and qualitative) changes contemplated by agriculturists and food technologists must, therefore, be carefully considered, and pilot studies should be carried out before these foods become widely available to the whole population.

Phenylketonuria illustrates how interaction of nutrient intake with a strong but rare genetic variation determines the difference between health and disease. In contrast, much more common but weaker genetic variations, interacting with nutrients, can moderately affect health in substantial proportions of populations. As an example, metabolism of the essential nutrients, linoleic acid and $\alpha$-linolenic acid, to essential longer chain fatty acids is under the control of genes. Common variations in such genes affect the efficiency of these metabolic conversions, so that dietary requirements for linoleic and $\alpha$-linolenic acid can vary significantly between individuals. As a corollary, since the absolute and relative amounts of dietary linoleic acid and $\alpha$-linolenic acid are associated with risk of coronary heart disease and cancers such as breast cancer, risk could vary between individuals with similar intakes of fatty acids as a function of variations in these control genes. In affluent countries, and for the rich, it is becoming possible to consider individual genetic variation in making dietary recommendations (personalized nutrition).

Obesity, type 2 diabetes, and certain kinds of cardiovascular disease and cancer are commonly called diseases of life-style. The term emphasizes individual rather than institutional responsibilities for avoiding disease, but in all cases the responsibility for promoting health is obviously dual. As an example, physical activity is, within wide limits, linearly related to good health, and the responsibility for adequate physical activity rests on government as well as the individual. Government must ensure the safety of physical environments so that its citizens are safe to walk and bicycle for local transportation, and government must formulate policies for education that ensure physical activity breaks for all primary and secondary education students. Urban environments must be free of pollutants, and urban architecture should encourage the involvement of citizens in activities such as local gardening of fruits and vegetables. Benefits include better citizenship, better diets, more physical activity and lower emissions of greenhouse gases.

The enormous population of humans depends on l'acido linoleico e l'acido $\alpha$-linolenico possono variare significativamente da individuo a individuo. Come corollario, poiché le quantità assolute e relative di acidi linoleico e $\alpha$-linolenico sono associate al rischio di cardiopatia ischemica e di alcuni tumori, come il cancro mammario, il rischio potrebbe variare tra individui con introduzioni simili di acidi grassi in funzione di variazioni in questi geni di controllo. Nei paesi ricchi, e per i ricchi, sta cominciando ad essere possibile considerare le variazioni genetiche individuali nel dare raccomandazioni dietetiche (nutrizione personalizzata).

L'obesità, il diabete di tipo 2, e alcuni tipi di malattie cardiovascolari e di cancro sono comunemente chiamate malattie dello stile di vita. Il termine malattie dello stile di vita enfatizza le responsabilità individuali piuttosto che istituzionali nell'evitare la malattia, ma in tutti i casi è ovvio che la responsabilità nel promuovere la salute sia duplice. Ad esempio, l'attività fisica è, entro ampi limiti, correlata linearmente con un buono stato di salute, ma la responsabilità di un'adeguata attività fisica sta sia nei governi sia negli individui. I governi devono assicurare la sicurezza degli ambienti fisici, sì che i cittadini possano camminare o andare in bicicletta in sicurezza, e sono loro a dover formulare politiche per l'educazione che assicurino interruzioni lavorative per attività fisiche per gli studenti nelle scuole primarie e secondarie. Sono i governi a dover assicurare che gli ambienti urbani siano liberi da inquinamento, e che l'architettura urbana incoraggi il coinvolgimento dei cittadini nello sport e in altre attività fisiche, quali ad esempio il giardinaggio con la coltivazione di frutta e verdura. I benefici di tali politiche comprenderebbero la promozione di uno Stato di migliori cittadini, migliori diete, più attività fisica ed emissioni minori di gas da trasporti urbani che contribuiscono all'effetto serra.

L'attuale enorme popolazione umana dipende dall'agricoltura per la maggior parte del cibo. L'agricoltura è anche l'attività umana maggiormente distruttiva dal punto di vista ecologico, ed è un importante contributo alle nostre emissioni di gas per l'effetto serra. L'impatto distruttivo dell'agricoltura dipende criticamente dalla scelta di che cosa decidiamo di coltivare e in che modo. La produzione di bestiame distrugge gli ecosistemi più di quanto facciano la produzione di frutta e verdure, ma l'impatto - distruttivo o sostenibile - dell'agricoltura o dell'allevamento dipende da quanto intelligentemente produciamo animali e piante commestibili. Per esempio, permettere ai bovini di pascolare invece che nutrirli con mangimi a base di cereali riduce l'emissione di metano. Allo stesso tempo, la salute dipende da che cosa e quanto mangiamo. Per continuare l'esempio, il rapporto acidi grassi omega-6 su omega-3 è inferiore nel latte ottenuto da mucche che pascolano rispetto a quello pro- 
agriculture for most of its food. Agriculture is also the most ecologically destructive of human activities, and it is an important contributor to our emissions of greenhouse gases. How destructive it is to farm depends critically on what and how we choose to farm. Producing livestock destroys ecosystems more effectively than producing fruits and vegetables, but whether we farm destructively or sustainably also depends on how intelligently we produce edible animals and plants. Allowing cows to graze rather than feeding them grains decreases emission of methane, for example. At the same time, health depends on what and how much we eat. To continue the example, the ratio of omega- 6 to omega- 3 fatty acids is lower in milk from cows that graze than cows fed grains. Eating large amounts of red meat (from cows, hogs, sheep and goats), moreover, increases the risk of common forms of cardiovascular disease and cancer. Moderate amounts of meat and dairy, however, can be valuable sources of protein. Such complex relationships indicate that we must align our policies for producing food and for preventing disease, and future dietary recommendations must be based on what we know about ecology and climate change as well as what we know about nutrition.

Most of the effects of global warming and climate change will make farming more difficult and food supplies more precarious. At the same time, agriculture contributes importantly to global warming and climate change, in part because contemporary agriculture, not least industrial agriculture, depends on burning fossil fuels for cheap energy. Energy in whatever form is expected to become much more expensive in the near future, however, and for this and other reasons, including environmental protection, food security, and public health, we need far more intelligent forms of agriculture. An example is the concept of agroecology as described in Olivier de Schutter's report on the right to food to the Human Rights Council of the United Nations in late $2010 .{ }^{1}$ Of equal importance, we need to integrate the results of the sciences of agriculture, nutrition and medicine. Agriculture must produce foods that we know are healthy to eat.

Large business interests partially finance and substantially affect the relevant science. The relationship of industrial agricultural interests to agricultural universities is a case in point. Food and agriculture scientists, moreover, have traditionally driven nutrition research and the development of products that were not proven beneficial to health (i.e. high amounts of omega-6 fatty acids in the food supply by changing animal feeds high in grains, trans fatty acids, and high fructose syrup, etc.). Instead, nutrition research and knowledge should define first what products are needed, and subsequently the food scientists and technologists grow and develop the products which should be pilot tested for safety and veniente da mucche alimentate con mangimi. Mangiare grandi quantità di carni rosse (da bovini, maiali, pecore e capre), inoltre, aumenta il rischio di forme comuni di malattie cardiovascolari e tumori. Quantità moderate di carne e latticini, tuttavia, possono essere una fonte preziosa di proteine. Queste complesse relazioni indicano che dobbiamo uniformare le nostre politiche di produzione del cibo per prevenire le malattie, e le future raccomandazioni dietetiche devono essere basate su quello che sappiamo sull'ecologia e i cambiamenti climatici, oltre che su quello che sappiamo circa la nutrizione.

La maggior parte degli effetti del riscaldamento globale e dei cambiamenti climatici renderà l'agricoltura e l'allevamento più difficili e il rifornimento di cibi più precario. Allo stesso modo, l'agricoltura contribuisce in maniera importante al riscaldamento globale e ai cambiamenti climatici, in parte perché l'agricoltura attuale, e non ultima l'agricoltura industriale, dipende dalla combustione di carburanti fossili per ottenere energia a basso prezzo. Si prevede che l'energia, in qualsiasi sua forma, diventi sempre più costosa nel vicino futuro. Tuttavia, per questo e altre ragioni - tra cui la protezione dell'ambiente, la sicurezza degli alimenti e la salute pubblica - abbiamo bisogno di forme molto più intelligenti di agricoltura. Un esempio è il concetto di agro-ecologia, come descritto nel rapporto di Olivier de Schutter sul diritto al cibo del Consiglio sui Diritti Umani delle Nazioni Unite del 2010. ${ }^{1}$ Di eguale importanza, è la necessità di integrare i risultati delle scienze agro-alimentari, della nutrizione e quelli della medicina. L'agricoltura deve produrre cibi che sappiamo essere sani da mangiare.

Grandi interessi finanziari in parte finanziano, ma influenzano in maniera sostanziale la pertinente produzione scientifica. La relazione degli interessi dell'agricoltura industriale con le università agrarie è uno di questi casi. Gli scienziati della nutrizione e gli scienziati agrari, inoltre, hanno tradizionalmente guidato la ricerca nutrizionale e lo sviluppo di prodotti che non sono stati dimostrati benefici per la salute (vedi le alte quantità di acidi grassi omega-6 nella catena alimentare introdotte con il cambiamento dell'alimentazione degli animali con cibi ricchi di cereali; l'introduzione di acidi grassi trans, e la popolarizzazione di bevande ad alto contenuto di fruttosio, etc.). Piuttosto, la ricerca nutrizionale e la conoscenza dovrebbero prima definire quali prodotti siano necessari, e successivamente gli scienziati e i tecnologi della nutrizione dovrebbero far crescere e sviluppare prodotti che dovrebbero essere comunque preventivamente valutati per la sicurezza e la salute prima che siano resi disponibili al pubblico. I dipartimenti di nutrizione dovrebbero condurre essi stessi la ricerca e lo sviluppo di prodotti, mentre i dipartimenti di scienze agrarie e di scienza e tecnologia degli ali- 
health before they are made available to the public. Nutrition departments should be leading in research and product development, and agriculture and food sciences and technology departments should play a secondary role instead of leading product development before nutritional benefit to humans, animals and the environment is established. If this were to happen, then the names of the various organizations should be changed from i.e. The Food and Nutrition Board to The Nutrition, Food and Agriculture Board indicating that nutrition research drives food and agriculture sciences research and technology. Similarly the food and agriculture organization (FAO) should change to Nutrition Food and Agriculture Organization. It would serve us better if nutritional research were to drive food sciences instead.

The complex problems of agriculture, food distribution, nutrition and human health in a setting of possibly disastrous ecosystem degradation and climate change can only be addressed intelligently by public and private policies based on science that is unbiased, critical and independent of special interests. We must, therefore, recognize the dangers inherent in the increasingly close ties between industry, government and university.

To be successful the following action is needed: i) agronomic, nutritional and medical science should be independent of business interests; ii) we need for new forms of agriculture such as agroecology; iii) future dietary guidelines to be based on ecological (including climatological) as well as nutritional science; iv) healthy oriented agriculture is needed to tailor the food chain to eradicate critical deficiencies and imbalances (e.g. change animal feeds to balance the omega6/omega-3 fatty acid ratio); v) a wide range of initiatives need to be implemented, particularly those that promote active life styles and community participation, such as sustainable neighborhoods, smart growth, public transport, oriented developments, networks of pedestrian and bicycle friendly paths; vi) food sources and food pathways and how they interact or not with the built environment of cities is critical; vii) reduce food deserts within towns and cities by increasing the availability of fresh fruit and vegetables through encouraging retail outlets in local urban environments.

In the fifth Century BC, Hippocrates set out the concept of Positive Health ${ }^{2}$ as follows:

Positive health requires a knowledge of man's primary constitution (author's note: which today we call genetics) and of the powers of various foods, both those natural to them and those resulting from human skill (author's note: today's processed food). But eating alone is not enough for health. There must also be exercise, of which the effects must likewise be known. The combination of these two things makes regimen, when proper attention is given to the season of the year, the changes of the winds, the age of the individ- menti dovrebbero invece giocare un ruolo secondario piuttosto che guidare lo sviluppo di prodotti prima che $i$ benefici nutrizionali per la salute umana, degli animali e dell'ambiente siano ben stabiliti. Se questo avvenisse, i nomi delle varie organizzazioni dovrebbero ad esempio essere cambiati da Consiglio per gli Alimenti e la Nutrizione a Consiglio per la Nutrizione, gli Alimenti e l'Agricoltura, a indicare che la Ricerca sulla Nutrizione guida e dirige la Ricerca in materia di Scienze e Tecnologie Agrarie. Allo stesso modo l'Organizzazione per il Cibo e l'Agricoltura (Food and Agriculture Organization, FAO) dovrebbe cambiar nome in Organizzazione per la Nutrizione, il Cibo e l'Agricoltura. Gli scopi ultimi sarebbero meglio raggiunti se la ricerca nutrizionale guidasse la ricerca nelle scienze degli alimenti.

I problemi complessi dell'agricoltura, della distribuzione dei cibi, della nutrizione e della salute pubblica nel contesto di una degradazione potenzialmente disastrosa degli ecosistemi e dei cambiamenti climatici possono essere affrontati intelligentemente solo da politiche pubbliche e private basate su una scienza critica e indipendente da interessi specifici. Pertanto dobbiamo riconoscere i pericoli inerenti ai rapporti sempre più stretti tra l'industria, i governi, e l'Accademia.

Per aver successo sono necessarie le seguenti azioni: i) le scienze agrarie, nutrizionali e mediche dovrebbero essere indipendenti da interessi commerciali; ii) c'è bisogno di nuove forme di agricoltura, come l'agro-ecologia; iii) le future linee guida dietetiche devono essere basate tanto su scienze ecologiche (comprendenti la climatologia) quanto sulla scienza della nutrizione; iv) c'è bisogno di un'agricoltura orientata alla salute per adattare la catena alimentare all'eradicamento di deficienze e sbilanciamenti critici (per esempio cambiare la nutrizione animale per bilanciare il rapporto di acidi grassi omega-6/omega-3); v) c'è bisogno di un ampio spettro d'iniziative, particolarmente quelle che promuovano comportamenti attivi, quali quartieri abitativi sostenibili, crescita intelligente, trasporti pubblici, sviluppi orientati, reti di percorsi pedonali e piste ciclabili; vi) è critico lo sviluppo di fonti di cibo e di catene alimentari che siano ben integrate con gli ambienti costruttivi delle città; vii) è importante ridurre i deserti di cibo negli ambienti urbani aumentando la disponibilità di frutta fresca e verdure con l'incoraggiare lo sviluppo di negozi al dettaglio in tali quartieri.

Nel quinto secolo avanti Cristo, Ippocrate articolò il concetto di Salute Positiva ${ }^{2}$ in questi termini:

La salute positiva richiede una conoscenza della costituzione primaria dell'uomo (nota dell'autore: che oggi chiamiamo genetica) e dei poteri dei vari cibi, sia di quelli naturali sia quelli risultanti dall'ingegno umano (nota dell'autore: i cibi processati di oggi). $M a$ la sola alimentazione non è sufficiente per la salute. Ci dev'essere anche l'esercizio, i cui effetti devono es- 
ual and the situation of his home. If there is any deficiency in food or exercise the body will fall sick.

Today, by focusing on the theme of Healthy Agriculture, Healthy Nutrition, Healthy People we seem to develop an integrated concept contributing to a healthy world. We must now consider how the participants of the Conference (scientists, medical doctors, academics, health promoters, agriculturists, government policy makers and industry representatives) can actually promote the goal of Healthy Agriculture, Healthy Nutrition, Healthy People in their own countries around the world. In this way, together we can work to accelerate progress in achieving a healthy world and reflect on the role of science in the process. Ultimately, in promoting Healthy Agriculture, Healthy Nutrition, Healthy People we are, in fact, promoting a single integrated model or perception of a healthy society. Therefore, these are not three independent concepts or goals, but rather integral parts of the whole that support and sustain a healthy society and environment.

\section{References}

1. de Schutter O. The right to food. A/65/281, 11 August 2010. Geneva: United Nations, General Assembly; 2010. Available from: http://daccess-dds-ny.un.org/doc/ UNDOC/GEN/N10/482/30/PDF/N1048230.pdf?Open Element

2. Hippocrates. Positive health. 480 BC. sere parimenti conosciuti. La combinazione di queste due cose costituisce il regime di vita, che dia adeguata attenzione alla stagione dell'anno, ai cambiamenti dei venti, all'età dell'individuo e alle condizioni della sua abitazione. Se c'è una carenza nel cibo o nell'esercizio il corpo si ammala.

Focalizzando l'attenzione sul tema di un'Agricoltura e una Nutrizione Sane per la Salute Pubblica, cerchiamo di sviluppare un concetto integrato che contribuisca a un mondo più sano. Dobbiamo ora considerare come i partecipanti a questo Convegno scienziati interessati, medici, accademici, promotori della salute, agronomi, governanti e rappresentanti dell'industria - possano promuovere gli scopi di un' $A$ gricoltura e una Nutrizione Sane per la Salute Pubblica nei rispettivi paesi del mondo, in modo che assieme possano lavorare per accelerare il progresso verso il raggiungimento di un mondo sano e far riflettere sul ruolo della scienza in tale processo. A lungo termine, la promozione di un'Agricoltura e una Nutrizione Sane per la Salute Pubblica permetterà di promuovere un singolo modello integrato o una singola unitaria percezione di una società sana. Questi pertanto non sono tre concetti o fini indipendenti, ma piuttosto parti integrali di un unicum che sostiene e supporta una società e un ambiente sani.

\section{Bibliografia}

1. de Schutter O. The right to food. A/65/281, 11 August 2010. Geneva: United Nations, General Assembly; 2010. Available from: http://daccess-dds-ny.un.org/doc/ UNDOC/GEN/N10/482/30/PDF/N1048230.pdf?Open Element

2. Ippocrate. Salute positiva. 480 AC. 